\title{
Service Quality, Customer Satisfaction, Perceived Value and Brand Loyalty: A Critical Review of the Literature
}

\author{
Phd. Student Elvira Tabaku
}

\author{
Faculty of Economy \\ "Aleksander Xhuvani" University, Albania \\ E.mail: tabakuelvira@gmail.com
}

\section{Prof. Assoc. Dr. Evis Kushi}

Faculty of Economy

"Aleksander Xhuvani" University, Albania

E.mail: eviscaku@yahoo.com

Doi:10.5901/ajis.2013.v2n9p223

\begin{abstract}
In increasing competitive markets, retaining actual customers and gaining new ones is the main aim of businesses. Businesses choose different ways for achieving customers and profits. One strategy businesses should adopt is building loyalty. Brand loyalty is seen as a successful mean of achieving market share and competitive advantages. While a lot of research exists to physically tangible products in their branding, little study has been given to branding in the services area. Given the significance of services to the global economy, this absence is worthy of further investigation. The main objective of this paper is to examine brand loyalty and some of its determinants in the service area. It uses secondary data from the existing literature to describe the importance of service quality, perceived value and customer satisfaction to brand loyalty. The findings demonstrate that customer satisfaction, perceived value and service quality are important constructs that determine brand loyalty. But research shows different scale of contribution of the single constructs to brand loyalty. These constructs must be studied interlinked with each other and with brand loyalty. Most of the research is done in developed countries. There is a need for further research according these constructs in developing countries, in different service settings and in different developing cultures.
\end{abstract}

Keywords: brand loyalty, customer satisfaction, service quality, perceived value

\section{Introduction}

The last decades, economies worldwide have undergone extensive social and economic transformation. One of the most important of these transformations is the growth of the service sector. Today, service sector is one of the most important of the economic activity of any society and is closely related with all other sectors of the economy. Service sector as other sectors is characterized by strong competition. Companies are always striving to retain existing customers and gaining new ones. In this increasingly competitive market, it is very important for any service organization to maintain strong and continuing relationships with customers. This will help it in the long term.

Loyalty is found to be an important construct of the long term financial performance of business firms (Reichheld, 1996). Many researchers (Aaker, 1996) think that brand loyalty is a premise to the firm's competitiveness and profitability and should be a strategy of achieving competitive advantages. So, brand loyalty is a very important construct for a firm to be a good market competitor. As a reaction to the significant increase in competition, for companies became fundamental creating and maintaining loyal customers. Businesses should seek to increase and maintain the share of customers. They must enclose customer loyalty within their business strategy. This is especially true for service firms where increased loyalty can largely increase profits which allow an organization to grow (Reichheld, 1996). The loyal customers help in doing marketing for the service provider and also they are more motivated to inform the management about a potential problem (Bowen and Shoemaker, 1998).

\section{Brand loyalty}

The final objective of the marketing process should be to hold existing customers, to gain new ones and to turn these 
customers into loyal ones and to keep and cultivate this relationship. From several decades, researchers and practitioners have recognized the importance of brand loyalty in the marketing literature (Aaker, 1996). Many researchers have studied brand loyalty and have found that it is an important issue of the marketing activities of an organization.

Different authors have given different definitions of loyalty. The most comprehensive definition of loyalty is forwarded by Oliver (1999). He states that brand/customer loyalty is a deeply held commitment to re buy or re patronize a preferred product/service/brand consistently in the future, thereby causing repetitive same brand or same brand set purchasing, despite situational influences and marketing efforts having the potential to cause switching behavior.

Loyalty can be important and valuable to both customers and the service provider. According to Aaker (1996), brand loyalty allows firms to employ price premium strategies. These strategies increase the level of cash flow. As loyal customers buy repeatedly the brand, they spend more on it and not only in one certain product but also in different products of the brand. The study of Bowen and Shoemaker (1998) found that loyal customers may return and purchase more in the service provider, perform partnership activities and are more likely to use other services of the service provider. Their study on the hotel industry, also showed that the loyal customer encourage other people to use the hotel service. In spreading the word of mouth they help the organization on doing marketing for it and help in reducing the marketing expenses of the organization.

Reichheld (1996) showed that a 5\% increase in customer retention consistently resulted in $25-100 \%$ profit increase, depending on the type of the service. So, brand loyalty leads to bigger market share as the same brand is purchased continuously. As the loyal customers use the same brand they are more confidential with it and as a result the level of trust on the brand is higher and the level of the risk of the loyal customers or other customer who they advice the service provider is reduced (Bowen and Shoemaker, 1998).

Brand loyalty, as an important instrument of marketing strategy, leads to many advantages. According to Rowley (2005), some of the benefits of brand loyalty are:

- lower customer price sensitivity

- reduced expenditure on attracting new customers

- improved organizational profitability.

According to Delgado-Ballester and Munuera-Aleman (2001), brand loyalty generates value to companies. It leads

in:

- a substantial entry barrier to competitors

- an increase in the firm's ability to respond to competitors threats

- greater sales and revenues

- a customer base less sensitive to the marketing efforts of competitors.

In the existing literature, customer loyalty has been defined and measured from different perspectives. The first is the behavioral perspective, the second the attitudinal perspective and the third one is composite loyalty (behavioral and attitudinal loyalty). So there are three main views of research in loyalty: one dimension of behavioral loyalty (Kandampully and Suhartanto, 2000), one dimension of attitudinal loyalty (Bennett and Rundle-Thiele, 2004) and two dimensions or composite loyalty (Day, 1969; Jacoby and Chestnut, 1978; Dick and Basu, 1994, Pritchard et al., 1999).

From the behavioral view, customer loyalty is defined as patronage, the proportion of times a consumer chooses the same service compared to the total number of purchases made by the consumer in that category (Rundle-Thiele and Bennett 2001).

Attitudinal loyalty is an attitudinal predisposition that consists on commitment to a brand, intention to repurchase the brand and an overall attachment to it (Mellens et al., 1996). Attitudinal concepts are manifested in providing positive word of mouth and recommending the service to the others (Zeithaml et al., 1996) and encouraging others to use the service (Bowen and Shoemaker, 1998).

The use of both behavioral and attitudinal components of loyalty was first proposed by Day (1969). According to Dick and Basu (1994), customer loyalty is the result of psychological processes and has behavioral manifestations, and should therefore incorporate both attitudinal and behavioral components. According to Jacoby and Chestnut (1978), brand loyalty is a construct that has both attitudinal and behavioral elements when defined as the biased (nonrandom) behavioral response (purchase) expressed over time by some decision-making units with respect to one or more alternative brands out of a set of such brands, which is a function of psychological (decision making, evaluative) processes.

There are several studies exploring the antecedents of loyalty. They show that loyalty is a complex issue. Different studies have shown that service quality, customer satisfaction and perceived value are frequently viewed as good predictors of brand and customer loyalty (Chen, 2008; Cronin et al., 2000). These studies have determined the 
relationships among customer perceptions of service quality, perceived value, customer satisfaction and post-purchase behavioral intensions (Chen, 2008; Cronin et al, 2000). According to Cronin et al. (2000), and Chen (2008), these constructs have been shown to be good predictors of behavioral intentions.

\section{Customer Satisfaction}

There is a lot of research about customer satisfaction. This research has aimed at exploring satisfaction and its outcomes. Many empirical studies show that satisfaction is a predictor of brand loyalty for consumer services (Pritchard et al., 1999).

When consumers are satisfied with the product or the service they are more prone to return and buy it again. This leads to a continuous behavior of the consumer and to a long term relationship. Studies on this field consider consumer satisfaction as a determinant construct leading to consumer behavior (Garbarino and Johnson, 1999). Different studies have proven that brand satisfaction is strongly correlated with the intention to repurchase and recommend (Kandampully and Suhartanto, 2000). Client satisfaction is generally assumed to be a significant determinant of repeat sales, positive word-of-mouth, and consumer loyalty (Kandampully and Suhartanto, 2000).

The theory of the expectancy disconfirmation was developed by Oliver (1980) and has been the base for conceptualizing customer satisfaction in retail and service industry from different researchers. Oliver (1980) proposed that satisfaction level is a result of the difference between expected and perceived performance. According to Zeithaml et al. (1996), the level of customer satisfaction depends on the ability of the supplier to meet the customer's norms and expectations.

Giese and Cote (2000) state that does not appear to be a consensus regarding the definition of customer satisfaction despite many attempts to measure and explain it. They think the way satisfaction is defined is important on interpreting its response. They think customer satisfaction is an affective response that varies in intensity, pertains to a particular focus and occurs at a particular time and is limited in duration. Satisfaction with previous purchase experiences plays an important role in determining future purchase behaviors (Pritchard et al., 1999). Several studies have stated that consumer satisfaction positively influences loyalty (Bowen and Shoemaker, 1998). Empirical evidence confirmed that satisfaction has strong influence on loyalty intention such as intention to recommend and intention to repurchase (Kandampully and Suhartanto, 2000). The study of Cronin et al. (2000) showed strong relationship between consumer satisfaction and loyalty.

In service industries is necessary a high level of contact between service providers and customers. The greater customer satisfaction with the service provider and with the all service experience, the more they feel they can trust both the organization itself and the personnel that provide its service.

Customer satisfaction is e requisite for loyalty but it is not for sure that satisfied customers may become loyal ones. Researchers have suggested that satisfaction is a necessary but not a sufficient condition for loyalty. This because satisfied customers would turn to other service providers whom they believe could offer them better value and quality (Bennett and Rundle-Thiele, 2004). Customer loyalty is not the same as customer satisfaction. The service provider can attain customer satisfaction without their loyalty, but it is difficult to have customer loyalty without their satisfaction (Shoemaker and Lewis, 1999). According to them, loyalty extends beyond simple satisfaction.

Most of the studies according customer satisfaction and loyalty only test the relationship between customer satisfaction and loyalty (Oh, 1999). So there is need for other research on customer satisfaction and brand loyalty in different service industries as this in may lead to different results.

\section{Service quality}

In recent decades, service quality has taken a lot of attention among practitioners, managers and researchers. This is attributed to the growing role of the service sector in the global economy. Many service firms have been using service quality as a differentiation tool. Service quality has a significant impact on business performance, business costs, customer satisfaction, customer loyalty and profitability (Seth et al., 2005). In the growing competitiveness, companies selling goods also are enriching their offer by using services. It is not easy to make evaluations through services' quality comparisons. This difficulty derives from the four distinct characteristics of services; intangibility, perishability, inseparability and heterogeneity. As a result, it is more complicated to achieve customer satisfaction and to establish competitive advantage in the service sector. The same, excellent quality must be delivered any time the service is delivered. So, service quality is crucial to the success of any service organization. Zeithaml (1988) defined service quality as the assessments of the costumers about a product's overall excellence or superiority. He states that services are 
difficult to evaluate because they contain many experience and credence attributes and because the service varies to different customers.

Different researchers state that there is no uniformly accepted definition of service quality as the service quality is difficult to define (Cronin and Taylor 1992; Parasuraman et al., 1993). The findings of the study of Athanassopoulos et al. (2001) in the banking sector indicate that when customers assess customer satisfaction to be high, they decide to stay with the existing service provider and subdue their negative behavioral intentions. Furthermore, their results indicate that customer satisfaction is associated positively with word-of-mouth communications.

The concept of perceived service quality is closely related with satisfaction and loyalty. In practice, service quality and satisfaction are often used interchangeably. Anderson and Sullivan (1993) state that satisfaction requires previous consumption experience and depends on price, while quality can be perceived without previous consumption experience and does not normally depend on price.

Some researchers have suggested that perceived service quality is an antecedent of customer satisfaction (Anderson and Sullivan 1993; de Ruyter et al., 1997). Others sustain that customer satisfaction precedes perceived service quality (Zeithaml and Bitner, 2003). This confusion about the relationship between satisfaction and perceived service quality may derive from absence of consensus on the definition and of the two constructs. The relationship between quality and satisfaction is complex.

The constructs of service quality, perceived value, and customer loyalty have been gaining increasing prominence in the marketing literature and in business practice and these constructs will continue to be critical (Parasuraman and Grewal, 2000). The study of Parasuraman and Grewal (2000) and previous ones support the general notion that service quality enhances perceived value, which, in turn, contributes to customer loyalty. They state that service quality is also a logical driver of perceived value and that service quality is much more difficult for competitors to copy effectively that is product quality.

Dick and Basu (1994) proposed that customers' belief to the service quality should lead to repeat patronage and increase their number of brand loyal customers.

Zahorik and Rust (1992) think that affecting perceived quality as an influencing factor of customer loyalty will provide significant ability to any model that includes customer loyalty as a dependent construct. Previous research has confirmed that the relationship between perceived quality and repurchase intentions, willingness to recommend and customer loyalty exists and is positive (Anderson and Sullivan 1993). As the matter of fact service quality has been identified as an agent that is able to affect directly customer satisfaction, repetition of purchase behavior and guarantee organization's long-term profitability (Zeithaml and Bitner, 2003).

Some researchers believe that service quality has a positive effect on brand loyalty (Zehir et al., 2011). Other researchers (Kim et al., 2008) have not found a direct and significant relationship between service quality and brand loyalty. Cronin et al. (2000) reported indirect relationship between service quality and behavior intentions in several service environments. Athanassopoulos et al. (2001) found that the customer satisfaction dimensions are industry specific and also country specific. So other studies in service quality and brand loyalty are needed.

\section{Perceived Value}

Many researchers suggest that customer perceived value is a strategic weapon in attracting and retaining customers and is one of the most significant factors in the success of service providers (Zeithaml, 1988; Zeithaml et al., 1996; Woodruff, 1997). According to Zeithaml (1988), perceived value is the customer's overall assessment of the utility of a product based on perceptions of what is received and what is given. Gale, (1994) assesses that customer value is market perceived quality adjusted for the relative price of your product and depends on the customer's opinion of products/services as compared to that of the competitors. According to Woodruff (1997), perceived value is the result or the benefit customers receive in relation to the price paid for the product/service.

The construct of perceived value has been identified as one of the most important elements for gaining competitive advantage and a very important indicator of repurchase intentions (Parasuraman and Grewal, 2000). Several authors state that perceived value affects satisfaction, customer loyalty, and other important outcomes (Cronin et al., 2000). Empirical research has shown that perceived value is a key determinant of repurchase intention (Cronin et al., 2000). Hu et al., (2009) performed a study to investigate the linkages among service quality, satisfaction, perceived value and image. The results indicated that that perceived value significantly affects customer satisfaction. So, the higher the perceived value the higher the client overall satisfaction with the service provider.

The study of Tam (2010) within the context of restaurant industry, suggests that perceived value has both direct and indirect effects on behavioral intentions. He suggests and proves empirically that service quality and perceived value 
are antecedents of customer satisfaction and client loyalty is a consequence of customer satisfaction. According to Dodds et al. (1991), the perception of value directly influences willingness to buy.

The results of the study of Oh (1999) showed that perceived value is an immediate antecedent to customer satisfaction and repurchase intention. It also affects directly and indirectly word of mouth through customer satisfaction and repurchase intention.

Research studies have suggested that perceived value may be a better predictor of repurchase intentions than customer satisfaction or service quality (Cronin et al., 2000; Woodruff, 1997). Some researchers have found that service perceived value is an antecedent of satisfaction, behavioral intentions (Cronin, et al., 2000; Dodds et al., 1991) and customer loyalty (Dodds et al., 1991). So, perceived value has a critical mediating role and a direct positive relationship with customer loyalty (Lemon et al., 2001). Furthermore, perceived value is found to have a significantly positive effect on overall satisfaction and both of them reveal significant positive effects on behavioral intentions in the airline service context (Chen, 2008).

Cronin et al., (2000) conduct a study to examine the effects of service quality, perceived value, and customer satisfaction on consumer behavioral intention in service environments. They found that service value is received primarily from perceptions of quality. So, in order of having service value consumers must view service quality of greater importance than the sacrifices they made. An important objective for delivering value to customers is to develop loyal customers who can increase purchase frequency, purchase quantity, and avoid switching behavior (Rust et al., 2004). According to de Ruyter et al., (1997) and Tam (2010), the role of perceived value in consumer behavior has received far lesser attention than service quality and customer satisfaction. Other studies are necessary to explore the role of perceived value.

\section{Conclusions}

Factors such as service quality, consumer satisfaction, and value are frequently viewed as key building blocks of customer loyalty (Chen, 2008). Cronin et al., (2000) provided evidence that customer satisfaction, value and quality directly influence behavioral intentions. A higher quality of service, perceived value and high levels of satisfaction can result in positive behavioral intentions and ultimately loyalty. In general authors agree that service quality, customer satisfaction and perceived value are important antecedents of brand loyalty. But only a few of them study these constructs as interlinked. They are intangible, complex and relatively vague, but also strategically important concepts. There are only a few researches which study the relationship between these factors in the same context. There is a need for studying these factors interlinked in the same context in different service industries. No research has simultaneously compared the relative influence of these three important constructs on service encounter outcomes (Cronin et al., 2000). This gap generates a new call for a research to examine simultaneously the relative influence of these constructs towards brand loyalty in the service sector. Also, most of the studies till now are done in developed countries, so there is a need to validate these models in developing countries, across different settings and cultures. According to Bowen and Shoemaker (1998), customer loyalty is particularly important to the hotel industry because of the strong competition. There are not similar studies in Albania. As tourism is considered an important means of development, there must be studies on it. The hotel sector is an important part of the holistic and tourism industry.

\section{References}

Aaker, D.A. (1996). Measuring brand equity across products and markets. California Management Review, 38, 102-20.

Anderson, E. W., \& Sullivan, M. W. (1993). The antecedents and consequences of customer satisfaction for firms. Marketing Science, 12(2), 125-143.

Athanassopoulos, A.,Gounaris, S. \& Stathakopoulos, V. (2001). Behavioral responses to customer satisfaction: an empirical study. European Journal of Marketing, 35(5/6), 687-707.

Bennet, R., \& Rundle-Thiele, S. (2004). Customer satisfaction should not be the only goal. Journal of Service Marketing, 18(7), 514-523.

Bowen, J.T. \& Shoemaker, S. (1998). Loyalty: A strategic commitment. Cornell Hotel and Restaurant Administration Quarterly, February, $12-25$.

Chen, C-F. (2008). Investigating structural relationships between service quality, perceived value, satisfaction, and behavioral intentions for air passengers: evidence from Taiwan. Transportation Research Part A: Policy and Practice, 42(4), 709-717.

Cronin, J. J. Jr., Brady, M. K. \& Hult, G. T. (2000). Assessing the determinants of consumer behavioral intentions in service environments: An investigation of a comprehensive model of the effects of quality, value, and satisfaction. Journal of Retailing, 76 (2), 193-218.

Day, G. S. (1969). A two dimensional concept of brand loyalty. Journal of Advertising Research, 9(3), 29-35. 
Delgado-Ballester, E. \& Munuera-Aleman, J. (2001). Brand trust in the context of consumer loyalty. European Journal of Marketing, 35, 1238-1258

De Ruyter, J.C., Bloemer, J.M.A. \& Peters, P. (1997). Merging service quality and service satisfaction: an empirical test of an integrative framework. Journal of Economic Psychology, 18, 387-406.

Dodds, W.B., Monroe, K.B., \& Grewal, D. (1991). Effects of price, brand, and store information on buyers' product evaluations. Journal of Marketing Research, 28(3), 307-319.

Dick, A. S. \& Basu, K. (1994). Customer loyalty: toward an integrated conceptual framework. Journal of the Academy of Marketing Science, 22, 99-113.

Gale, B. T. (1994). Managing Customer Value. New York, NY: The Free Press

Garbarino, E. \& Johnson, M. S. (1999). The differential roles of satisfaction, trust, and commitment in customer relationships. Journal of Marketing, 63, 70-87.

Giese, J. L. \& Cote, A. J. (2000). Defining consumer satisfaction. Academy of Marketing Science Review, http://www.amsreview.org/amsrev/theory/giese01-00.html

Jacoby, J. \& Chestnut, R. (1978). Brand loyalty: Measurement and management. New York, Wiley.

Hu, H., J. Kandampully \& Juwaheet, T. (2009). Relationships and impacts of service quality, perceived value, customer satisfaction and image: An empirical study. Journal of Services Industry, 29(2), 111-125.

Kandampully, J. \& Suhartanto, D. (2000). Customer loyalty in the hotel industry: the role of customer satisfaction and image. International Journal of Contemporary Hospitality Management, 12(6), 346-351.

Kim, J. Y., Morris, J. D., \& Swait, J. (2008). Antecedents of true brand loyalty. Journal of Advertising, 37, 99-117.

Lemon, K.N., Rust, R.T., \& Zeithaml, V.A. (2001). What drives customer equity? Marketing Management, 10(1), 20-25.

Mellens, M., Dekimpe, M. G. \& Steenkampe, J. B. E. M. (1996). A review of brand-loyalty measures in marketing. Tijdschrift voor Economie en Management, 41 (4), 507-533.

Oh, H. (1999). Service quality, customer satisfaction, and customer value: A holistic perspective. International Journal of Hospitality Management, 18(1), 67-82.

Oliver, R. L. (1980). A cognitive model for the antecedents and consequences of satisfaction. Journal of Marketing Research, 17, 460469.

Oliver, R.L. (1999). Whence Consumer Loyalty. Journal of Marketing, 63, 33-44.

Pritchard, M. P., Havitz, M. E. \& Howard, D. R. (1999). Analyzing the commitment loyalty link in service contexts. Journal of the Academy of Marketing Science, 27 (3), 333-48.

Parasuraman, A., Berry, L. L. \& Zeithaml, V. A. (1993). More on improving service quality Measurement. Journal of Retailing, 69, $140-47$.

Parasuraman, A., \& Grewal, D. (2000). The impact of technology on the quality-value-loyalty chain: A research agenda. Journal of Academic of Marketing Science, 28, 168-174.

Reichheld, F. (1996). The loyalty effect: The hidden force behind growth, profits and lasting value. Boston: Harvard Business School Press.

Rowley, J. (2005). The Four Cs of Customer Loyalty. Marketing Intelligence and Planning, 23(6), 574- 581.

Rundle-Thiele, S. \& Russell-Bennett, R. (2001). A brand for all seasons? A discussion of brand loyalty approaches and their applicability for different markets. Journal of Product and Brand Management, 1 (10), 25-37.

Rust, R.T., Lemon, K.N., \& Zeithaml, V.A. (2004). Return on marketing: Using customer equity to focus marketing strategy. Journal of Marketing, 68(1), 109-127.

Seth, N., Deshmukh, S.G. \& Vrat, P. (2005). Service quality models: a review. International Journal of Quality \& Reliability Management, 22(9), 913-49.

Shoemaker, S., \& Lewis, R. C. (1999). Customer loyalty: the future of hospitality marketing. International Journal of Hospitality Management, 18, 345-370.

Tam, J.L.M. (2000). The effects of service quality, perceived value and customer satisfaction on behavioral intentions. Journal of Hospitality and Leisure Marketing, 6(4), 31-44

Woodruff, R. B. (1997). Customer value: the next source for competitive advantage. Journal of the Academy of Marketing Science, 25, 139-153.

Zahorik, A. J. \& Rust R.T. (1992). Modeling the impact of service quality on profitability: A review. Advances in Services Marketing, 1, JAI Press, 247-76

Zehir C., Sahin A., Kitapçı H. \& Özsahin M. (2011). The effects of brand communication and service quality in building brand loyalty through brand trust; the empirical research on global brands. Procedia- Social and Behavioral Sciences, 24, 1218-1231

Zeithaml, V. A. (1988). Consumer perceptions of price, quality and value: a means-end model and synthesis of evidence. Journal of Marketing, 52, 2-22.

Zeithaml, V. A., Berry, L. L., \& Parasuraman, A. (1996). The behavioral consequences of service quality. Journal of Marketing, 60(2), $31-46$.

Zeithaml, V. A., \& Bitner, M. J. (2003). Services Marketing: Integrating Customer Focus across the Firm. Boston, MA, McGraw-Hill Irwin. 